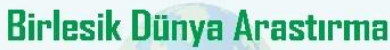 BD-CENTER \\ World Journal on Educational \\ Technology: Current Issues
}

\section{Dynamic characteristics of students' communicative behavior in social networks}

Vera B. Nikishina ${ }^{\mathrm{*}}$, Faculty of Psychology and Social, Pirogov Russian National Research Medical University, Moscow, Russia. https://orcid.org/0000-0003-2421-3652

Marina V. Sokolskaya ${ }^{b}$, Department of Social Work, Pirogov Russian National Research Medical University, Moscow, Russia https://orcid.org/0000-0002-5693-2021

Oksana A. Musatova c, Department of Social Work, Pirogov Russian National Research Medical University, Moscow, Russia. / Department of General Psychology and Labor Psychology, Institute of Psychology and Pedagogy, Russian new University, Moscow, Russia. https://orcid.org/0000-0001-8893-4059

Irina V. Zapesotskayad, Department of Organization Continuing Education, Pirogov Russian National Research Medical University, Moscow, Russia. https://orcid.org/0000-0003-3535-5779

Alina V. Danilovae, Department of Health Psychology and Neuropsychology, Kursk State Medical University, Kursk, Russia. https://orcid.org/0000-0003-1064-5550

Anna M. Balykinaf, Department of Basic Mathematics and Computer Science, Russian New University, Moscow, Russia. https://orcid.org/0000-0003-0815-3557

\section{Suggested Citation:}

Nikishina, V.B., Sokolskaya, M.V., Musatova, O.A., Zapesotskaya, I.V., Danilova, A.V.\& Balykina, A.M. (2021). Type the title of your paper. World Journal on Educational Technology: Current Issues. 13(4), 863-889. https://doi.org/10.18844/wjet.v13i4.6272

Received from July 26, 2021; revised from August 01,2021; accepted from October 25, 2021

Selection and peer review under responsibility of Prof. Dr. Servet Bayram, Yeditepe University, Turkey.

(C)2021 Birlesik Dunya Yenilik Arastirma ve Yayincilik Merkezi. All rights reserved.

\section{Abstract}

Dynamic characteristics of social networks users' behavior represent the toolkit for diagnosing the character and orientation of cyber communication. This study aims to analyze the communicative behavior of youth after transitioning directly from direct communication to communication via technology for the purpose of defining opportunities and determining manipulation potential on communicants. Sixty-two (62) active participants of social networks were selected to answer the questions of the questionnaire. Further, on the grounds of the provided statistics of their accounts, quantitative characteristics of dynamics of cyber communication of participants' communicative behavior were analyzed using descriptive statistics and $r$ criterion of Spearman rank correlation. From the results, decrease in the level of intellectual communication of the youth in cyberspace provides a high level of the youth manipulative availability in social networks. Hypotheses about measurability of dynamic characteristics of cyber communication, as well as the communication vector shift from small groups into big ones were confirmed.

* ADDRESS FOR CORRESPONDENCE: Vera B. Nikishina, Faculty of Psychology and Social, Pirogov Russian National Research Medical University, Moscow, Russia.

E-mail address: $\underline{\text { VBNikishina@mail.ru }}$ 
Nikishina, V.B., Sokolskaya, M.V., Musatova, O.A., Zapesotskaya, I.V., Danilova, A.V.\& Balykina, A.M. (2021). Type the title of your paper. World Journal on Educational Technology: Current Issues. 13(4), 863-889. https://doi.org/10.18844/wjet.v13i4.6272

Keywords: dynamic characteristics of communication, cyber communication, social networks, meme, repost, post.

\section{Introduction}

Information technologies, currently being the main source of innovative transformations movement, provide contents, form, structure, and quality of interpersonal communication to the significant extent. Communicative processes obviously and actively move to cyberspace (Owan, Ekpe \& Eneje, 2020). Cyberspace represents the virtual social field of human life represented within the interaction of a computer, networks and a person; the appearance of cyberspace is caused by the set of the IT industry manifestations, creating new technologies of interpersonal interaction (Baryshev, 2008; Shaidullina et al., 2015; Minakhmetova et al., 2017; Sudakova et al., 2017; Mukhametshin et al., 2019; Razumovskaya et al., 2018, 2019; Nurieva \& Inozemtseva, 2020; Gimaliev et al., 2020; Yushau \& Nannim, 2020; Valeeva, Baykova \& Kusainov, 2016; Privalova et al., 2019). The main characteristics of cyberspace are coherence and informational content completeness, sociality - fullness of people images, which are supported by texts, video and audio information, images (Galiullina, 2018; Levina et al., 2019; Orekhovskaya et al., 2019; Khairullina et al., 2020).

In 2019 the global network (GlobalWeblndex, 2019) which was initially developed as means of the academic information exchange all over the world turned 30. At the moment the global network integrates communicative functions, such as involvement in communication of big social groups and distances levelling (Bargh \& McKenna, 2004; Jabbar \& Hussin, 2019). According to the joint "Report on global condition of digital technologies" (Digital, 2019: Global Internet Use Accelerates, n.d.) of the international agency "We Are Social", which specializes in researches in the sphere of social media and Hootsuite social networks management platforms, by the beginning of 2019 there were 5.11 billion digital technologies mobile users (for a total number of the world population 7.676 billion people), and 4.39 billion people of Internet users worldwide.

Social networks are a segment of global network and cyberspace and characterized cyberspace social structure, which is determined by the processes of formation, distribution, consumption of information, norms of network ethics, procedures of interaction with offline social establishments (Kvon et al., 2019; Bayanova et al., 2020; Salakhova \& Khabibullin, 2018; Danilova \& Kondratyeva, 2019; Drozdikova-Zaripova \& Davlieva, 2019; Galchenko et al., 2020; Rubio et al., 2020). Social networks by the beginning of 2019 comprised 3.48 billion registered users. The general dynamics of growth, both in number of Internet users and social networks users is about $10 \%$ a year. In total for the last five years (since 2014) the number of Internet users around the world has increased by $75 \%$ (by 1.9 billion people). According to the report on average, a person is online 6 hours and 42 minutes a day (users of the Russian segment on average spend 6 hours 29 minutes a day on the Internet). Social networks act as an intensive segment of information communication, taking the essential share in the total amount of time and in the general array of Internet content (Digital, 2019).

The level of involvement in social networks of all new users in the world was 45\%, and in 2018 288 million new accounts have been registered in social networks. Thus, since 2014 the total number of social networks users in the world has almost doubled. The provided data reflect the situation concerning the so-called "adult population", i.e., users older than 13 years old. According to the data of Hootsuite (Hootsuite, 2019) the bulk of users of social networks Facebook, Instagram and Facebook 
Messenger is differentiated by age as follows: $13-17$ years old- $5 \%, 18-24$ years old $-27 \%$, 25-34 years old $-32 \%$, 35-44 years old $-16 \%$, $45-54$ years old $-10 \%, 55-64$ years old $-6 \%$, more than 65 years old - 4\%. Concerning the amount of time spent by users in social networks its steady growth is noted. According to the data of Global Web Index (GlobalWeblndex, 2019), the average user spends 2 hours 16 minutes daily on social networks that makes the third part of the total time spent on the Internet. The dispersion on this indicator in the world is rather high: from 36 minutes to 4 hours 12 minutes. The Russian user occupies a median position with the indicator coinciding with the world average -2 hours 16 minutes. The percent of social networks active users among the leading countries on the indicator of time spent on social networks makes $83 \%$. Thus, it is obvious that social networks firmly and definitively take the essential part of interpersonal communication. At the same time, providing the user with innovative functionality, it is natural to assume that social networks transform the dynamic characteristics of communicative processes.

\subsection{Cyberspace: Appearance of the Term, Direction of Research}

The term "cyberspace" came into scientific parlance from fiction, for the first time it was used by the Canadian science fiction writer W. Gibson in 1982 in the novel "Burning Chrome". The term "cyberspace" got into scientific literature in 1990, however the first works (1990-1991) were devoted to the design of the computer environment (that is exactly how the cyberspace was interpreted in research practice of the specified period) and actually were not noticed, having received from 2 to 12 citings.

Romkey's (1991) investigation on "Whither cyberspace?" for the first time accented not specially - technical, but common cultural aspects of cyberspace in order to define the value of "cyberspace" concept. Owing to the prevalence of the generalizing judgments about the perspective development of cyberspace and lack of concrete conclusions, the work did not draw close public attention. However, in 1991 exactly the issue of cyberspace was publicly introduced to the international community.

Up until 1996, cyberspace had been investigated as a means of cooperation (Harasim, 1993; Allen, 1996). Organizational and legal aspects of information technologies and cyberspace usage (Branscomb, 1994; Johnson \& Post, 1996; Lessig, 1996; Thach \& Woodman, 1994), investigations ethics in cyberspace (Allen, 1996; Alun, 1994; King, 1996; Thomas, 1996), bibliometric investigations in cyberspace (Larson, 1996) and training in cyberspace (Dumont, 1996) were analyzed. Particular emphasis had been placed on the investigations on religion propagation in cyberspace (O'Leary, 1996), computer infrastructure, problems of society information overload (Berghel \& Hal, 1997). Cyberspace was also investigated as the tool for social movements (Froehling, 1997) and financial interaction (Birch \& Young, 1997). Forms and borders of cyberspace also appeared in scientific research focus (Batty \& Barr, 1994).

In the specified array of investigations, at the same time, till 1996 the issue of information technologies is practically not fixed in scientific psychology publications. Since 1996 the subjects of psychological orientation actively begin to take the leading positions, mainly involving the communication issue mediated by the information and technological environment (Riva \& Galimberti, 1997; Wynn \& Katz, 1997), behavior deviations in cyberspace (Durkin \& Bryant, 1995), romantic relations in network (Cooper \& Sportolari, 1997), online communities anthropology (Wilson \& Peterson, 2002), virtualizations of corporality of such communication and its influence on psychological parameters (Biocca, 2006). 
It is precisely in accordance with communication psychology questions in cyberspace, subjectivity in network reality, interactions of the subject, network reality, and scientific works, which widely obtained recognition of scientific community appeared. The latter include publications on the affiliative processes in Networks investigation (Parks \& Floyd, 2006) devoted to the communication quality change in the conditions of Internet communication (Bargh \& McKenna, 2004). The issue of the Internet involvement consequences for the development of personal qualities, formation of personal identity, social interaction and the relations is also popular (McKenna \& Bargh, 2000). Certainly, the scientific works analyzing the nature of interpersonal relations formation on the Internet (McKenna, Green \& Gleason, 2002) and processes of creation of virtual communities are in demand (Wellman et al., 1996).

Extremely topical subject of psychological investigations in cyberspace is cyberbullying (Festl \& Quandt, 2016; Juvonen \& Gross, 2008; Patchin \& Hinduja, 2006). In their research K. Allison and K. Bussey (2017) proved that 'individuals' perceptions of social norms moderate the influence of individual morality on intervention'. Analyzing problems of cyberbullying and racism on the Internet from the point of view of its demonstration, B.T. Keum and M.J. Miller (2018) note that 'online specific factors such as increase of anonymity and "digital freedom of speech" have allowed users to freely disclose their ideologies for the public to witness without fear of consequence and direct responsibility'.

\subsection{Cyber Communication}

All the above-mentioned investigations, nevertheless, are more or less connected with the communication issue in the context of information exchange and its presentation in cyberspace, and, in particular, communication in social networks. The demand of this topic is confirmed by high quoting of scientific works on the subject "network communication" ("network communication" / "internet communications" / "cyber communication" / "social networking") limited only by the sphere of "Psychology". So, the array of publications with the specified restrictions in Scopus base contains 3396 works with $112 \mathrm{H}$ - index.

The most pertinent investigations (according to the high citation criterion) are the ones devoted to the interrelations problems of personal factors and motivation for communication in social networks (Andreassen et al., 2012; Cheung, Chiu \& Lee, 2011; Correa, Hinsley \& de Zuniga, 2010; Lin \& Lu, 2011; Nadkarni \& Hofmann, 2012; Ross et al., 2009; Ryan \& Xenos, 2011); to the self-presentation problem in social networks (Buffardi \& Campbell, 2008; Krämer \& Winter, 2008; Manago et al., 2008; Mehdizadeh, 2010; Seidman, 2013; Zhao, Grasmuck \& Martin, 2008); roles of networks in social interaction (Forest \& Wood, 2012; Hughes et al., 2012; Jacobsen \& Forste, 2011; Manago, Taylor \& Greenfield, 2012; Pempek, Yermolayeva \& Calvert, 2009); to the problem of risks - taking, trust and confidentiality in the network (Fogel \& Nehmad, 2009; Hinduja \& Patchin, 2008; Nosko, Wood \& Molema, 2010). More and more relevant sounds the issue of communication ghettoization in the network considering the tendency of individuals to associate and bond with similar other (Murase et al., 2019) when social interaction within closed groups may function as a form of safety behavior for socially anxious people seeking to avoid face-to-face encounters (Kamalou, Shaughnessy \& Moscovitch, 2019). In particular, the specified issue is relevant for the communities treated by most of the population as "others". It is interesting that the comparative analysis shows that the extent of segregation for different religions is much higher than that for different races and slightly higher than that for different political parties (Hu, Zhang \& Zhou, 2019). 
The issue of social networks users' deviant self-presentation in the process of cyber communication when empathy, narcissism, and self-esteem may play an important role in the use of networks was widely disseminated (Errasti, Amigo \& Villadangos, 2017; Piralova et al., 2020). Sexual harassment existence on the Internet and its influence on cyber communication and social networks users' offline socialization is of growing concern within society (Dahlqvist et al., 2016; Festl \& Quandt, 2016; Festl, Reer \& Quandt, 2019).

The appearance of all new investigations in the context of psychological investigations updated the necessity for their systematization and generalization. Also surfacing, were some works analyzing the existing literature on empirical investigations, aimed at the identification of the status and characteristics of a user as a participant of online community (Gillath, Karantzas \& Lee, 2019; Huang, 2019; Malinen, 2015). So, Malinen (2015) demonstrated in his investigation that that a theoretical and conceptual framework for user participation remains undefined, despite the vast research conducted on the subject, which has mostly addressed participation in terms of its quantity, having updated the necessity for further systematization and the analysis of cyber communication literature. The systematic review of the existing literature on the cyber communication issue carried out by the author allowed to allocate the following prevailing thematic fields: (1) Users' individual characteristics and their relation to participation (motivations, personality traits, values, and benefits that are perceived from participation; different user types and their changeability); (2) social influence that people have on each other in online communities; (3) technology of communication (how to facilitate participation with successful user-interface design and create optimal conditions for participation); (4) organizational aspect: online community can serve, for instance, as an instrument of knowledge-sharing in professional development and in educational landscape; (5) business perspective: online communities can increase brand loyalty, trust, and interest in the products, improve customer relationship, and attract new customers (Malinen, 2015). In our opinion, communicants' motivation for communicative interaction and the issue of communicants' social interference in cyberspace appear to be the most crucial. Individual socialization and self-identification are defined today by the nature of communication which develops mainly in cyberspace, due to its specific peculiarities to speak how the communication participant would like, often without appealing to the regulating social norms. Social networking sites offer new avenues for interpersonal communication that may enable people to build social capital [(both bridging and bonding) (Liu, Ainsworth \& Baumeister, 2016)], and formation of this capital in the conditions of rapid online and offline realities' merge in the youth consciousness is capable of radically shakin g a habitual social landscape.

\subsection{Cyber Socialization, Social Identity and Communication Nature}

Online self-presentation is highly influenced by peer norms (Baumgartner et al., 2015) that induces some users to consciously challenge these norms with the purpose of brighter self-presentation, but in the long-term similar behavior leads to the self-identification erosion. The idea is that cyber communication leads to the creation of virtual cognitive niches, which "can be considered as digitallyencoded collaborative distributions of diverse types of information into an environment performed by agents to aid thinking and reasoning about some target domain (Arfini, Bertolotti, \& Magnani, 2019). The issue acquires special relevance through the prism of the fact that online communities, as networks displaying a social bias, can both foster civic awareness and promote problematic group-led behaviors in the virtually aggregated crowds (Arfini, Bertolotti, \& Magnani, 2019). At the same time, through social network sites people gain information about acquaintances that they would not gain from everyday life. 
From here looking at another user's profile influences perceptions of that individual's socially desirable characteristics (e.g., intelligence, attractiveness) (Vogel \& Rose, 2017) which can acquire non traditional sounding of the conventional morality.

Socialization realized in the process of cyber communication with the usage of social networks needs careful attention from society, as its contours are capable to change the social landscape radically. At the same time, the nature of communication is extremely mobile and even intercultural communication styles are fluid rather than fixed (Sandel, Buttny \& Varghese, 2019; Zakaria, 2017). In the background of more and more actively gaining momentum cyberbullying and trolling in online communication context (Jenks, 2019), the development of digital civility which formation is preferably to be incorporated in the school program is necessary (Dishon \& Ben-Porath, 2018; Krishnan, 2016).

In Wilson, Gosling and Graham (2012) work the overview of Facebook role in the communication of its users is presented. Five categories of investigations have been singled out by the authors: descriptive analysis of users; motives for Facebook usage; presentation of the personality; Facebook role in social interactions; confidentiality and disclosure of information. As a result of the carried out investigation, the authors came to the following conclusions: (1) the actions carried out in Facebook are a convincing source of measurable behavior traces as they leave behind a set of concrete observed data; (2) social networks do not only reflect the existing social processes, but also generate new ones, changing a way duty to which hundreds of millions of people belong to each other and exchange information (social connections strengthening, confidentiality and information disclosure issue), and the increasing social networks integration into daily life updates the necessity of studying positive and negative aspects of their impact on society; (3) the average user of social networks has 130 friends, brings into cyberspace 90 units of content a month and is connected on average with 80 pages, groups and community events; (4) as the most widespread internal motivation for communication stands the users' desire to keep in contact with friends. Wilson, Gosling and Graham (2012) presented the identity analysis as the process by means of which Facebook users associate themselves with cyber community. The identity presentation in Facebook is concentrated around the user's profile which can be changed by its creator proceeding for reasons of his self-presentation and cyber identification that calls into question its relevance. In fact, the page of a Facebook profile represents an empty canvas on which each user can freely create his public or semi-public image. The study of the process by means of which this image is created gives a new view on identity formation and interpersonal interactions studying in Facebook gives an unprecedented opportunity for the exploration of a wide range of social phenomena in naturalistic conditions.

Subrahmanyam et al. (2008) investigated the nature of the websites of social networks' usage by young people and also the types of interrelation of their network with their friends in online (for example, instant messaging) and offline networks. The authors of the investigation established that being offline the participants more often talked on the phone, studied, watched TV, and communicated with friends. On the Internet the most frequent types of activity became e-mail, viewing of web pages and visiting of websites and social networks. College students taking part in the investigation used social networks websites as means of communication maintenance with their friends and also members of their families and relatives (Bayanova et al., 2019; Maksyutova, 2019; Montaner, 2020). Only a third of participants reported that they have a profile on social network to meet new people and to get new friends, and the smaller percent reported that they use them for communication. The most part of users' time spent on the websites of social networks was spent on reading comments, writing comments and 
responses to comments / messages; viewing of pages / profiles and walls of friends that, in turn, helps users to trace their friends, events in their lives and also interaction of their friends with the others. The authors proved that offline and online worlds are connected, and users use online communication for the solution of questions in offline mode and for the communication with people in the offline lives. At the same time, offline and online worlds of users of social networks are not mirror reflection of each other. In practice, distancing of the specified worlds take place when disadvantages of offline communication are compensated in online reality. Thus, the extensive potential of manipulation by both own identity and its self-presentation in group cyber community is implemented (Salakhova, 2019; Shirokova, 2019; Sinyagina \& Artamonova, 2019).

The aim of the given investigation is the identification of peculiarities of dynamic characteristics of communicative behavior of the youth in the transition from direct communication to the communication mediated by information technologies for the purpose of definition of opportunity / extent of potential manipulative impact on the communicant. According to the authors' hypothesis, the dynamic characteristics of communicative behavior in objective reality represent the specific phenomena of social life connected with the exchange of information in group according to the parameters of activity (inclusiveness), volume (the number of participants) and duration; from here, considering specifics of communicative behavior on social networks, dynamic parameters in the reality mediated by technical means are measured. The second hypothesis was the provision on cyberspace communicants' desire to realize communication in big, but not small groups.

\subsection{Theoretical Foundation}

Despite the proved interrelation between the social network's users' offline and online worlds, the thesis stating that communicative behavior's structure and dynamics change in social networks is unquestionable. The dynamic characteristics of communicative behavior in objective reality represent the specific phenomena of social life connected with the information exchange in the group according to the parameters of activity (inclusiveness), volume (the number of participants) and duration. Taking into consideration the specificity of communicative behavior in reality mediated by technical means (social networks), its dynamic parameters are measured in difference from those in the reality which is not mediated by technical means. Quantitative indices of communicative behavior's dynamic parameters in social networks will be: quantity of posts and reposts on the wall, quantity of likes, quantity of messages and responses to messages, quantity of comments, quantity of Internet memes (as inclusiveness indicators), quantity of personal information about the user, statistics of a profile, openness / closeness of a profile (as indicators of participants number and volume of personal information), active time of stay in social network (as duration indicators).

\section{Materials and Methods}

\subsection{Participants}

The total amount of empirical selection comprised 62 people. The selection was equalized according to the gender (male -25 and female -37 ) and were eliminated according to age (from 18 to 25 years old, middle age $-21.4 \pm 0.56$ ) and language factors (communication in Russian). For the research users with "open" accounts, daily activity on social network and duration of social network usage not less than a year were selected. 


\subsection{Procedure}

The investigation was carried out in social networks "VKontakte", "Facebook" and "Twitter" during the period from 03.06.18 till 28.01.19 and included three consecutive stages: (1) on the platforms of the largest social networks communities (not less than 100 thousand subscribers) the post was published inviting users to participate in the investigation and also the selection criteria of participants (frequency of social networks use, age, the status of the account) were mentioned; (2) to all the users who responded to the post it was offered to fill out the questionnaire and to provide the statistics of their page; (3) the obtained data was analyzed, its statistical processing was realized. Data of the users who did not provide full information in the questionnaire / refused to transfer the statistics of their pages were excluded from the investigation. Survey and Behavioral Research Ethics Committee of Russian Academy of Education has granted approval in principle for authors to conduct the survey of human behavior by non-clinical means.

\subsection{Data Collection tool}

The investigation procedure included the analytical review of a social network user' profile and a user' survey which was carried out by means of the questionnaire composed by the authors. The reference to the questionnaire created in Google forms was sent to the user (See Appendix 1). Questioning was not anonymous as the analysis of the user's account was based on the questionnaire completed by him. In the questionnaire it was necessary for the users to give authentic answers on the following categories: the quantity of marks "like" under comments, posts, and photos; the number of comments under posts, photos and in response to other users' comments; the number of the sent messages and the number of responses to messages; the number of the used Internet memes with negative, positive, or comic sense. Also, the unloading of page statistics which is automatically generated by the social network, on condition of the presence of at least 50 online user's friends was requested.

\subsection{Analysis}

For the analysis of the obtained data the methods of descriptive statistics (fashion, midpoint, mean square deviation) and also r-criterion of Spearman rank correlation were used.

\section{Results and Discussion}

\subsection{Results of analysis of comparative characteristics of small and big groups in offline and online realities communication}

The scientometric argumentation of relevance of the analysis of communicative behavior on social networks problem requires transcending to the specification of psychological maintenance of dynamic parameters of communicative behavior. Having analyzed Pervushina, Savushkina and Hutorny (2017), Vylkov (2009), Bondarenko (2004) researches the authors of the current paper singled out features typical for Russian-speaking users communication in social networks caused by specifics of cyberspace (See Table 1). Also, comparative characteristics of small and big groups in offline and online realities communication were analyzed (See Tables 2 and 3). 
Table 1:Characteristic of cyberspace

\begin{tabular}{|c|c|}
\hline $\begin{array}{l}\text { Characteristic } \\
\text { cyberspace }\end{array}$ & Content \\
\hline Distance in cyberspace & $\begin{array}{l}\text { Space connects to time. For example, the time of two computers' } \\
\text { connection in network can be considered as the way of distance } \\
\text { determination; or the average number of following links which is } \\
\text { necessary to reach a certain website it is also possible to correlate to } \\
\text { distance between users. }\end{array}$ \\
\hline $\begin{array}{l}\text { Absence of typical social } \\
\text { barriers }\end{array}$ & $\begin{array}{l}\text { Gender and age distinctions are erased (that is why the age of group } \\
\text { participants can vary significantly), appearance peculiarities do not play } \\
\text { any role, the social status is not important, the level of communicative } \\
\text { abilities (verbal) does not play the defining role. Social and individual } \\
\text { taboos do not matter. }\end{array}$ \\
\hline $\begin{array}{l}\text { Coherence } \quad \text { and } \\
\text { informational content } \\
\text { substantial completeness }\end{array}$ & $\begin{array}{l}\text { The reflection of all the positions and all the points of view on any } \\
\text { problem. High degree of information update. Combination of the } \\
\text { standard language of the users' environment with teenage and youth } \\
\text { slang, Internet, and subcultural languages elements, intra - group } \\
\text { peculiarities of speeches / texts. }\end{array}$ \\
\hline Artificial socialization & $\begin{array}{l}\text { Cyberspace is filled with the images of people generated texts, photo, } \\
\text { video and audio information. The provided information in most cases } \\
\text { includes fake elements. The anonymity prevails. "Friends" in the account } \\
\text { (especially within communication in big groups) in offline are not } \\
\text { acquainted as a rule. }\end{array}$ \\
\hline $\begin{array}{l}\text { Mediated } \\
\text { technologization }\end{array}$ & $\begin{array}{l}\text { Cyberspace technologies are operated by people and change over time. } \\
\text { Technologies adapt to customers' needs. }\end{array}$ \\
\hline
\end{tabular}

In no mediated reality, the leading share of communicative behavior is concentrated in small groups. In social networks the communicative activity turns toward realization in big groups. The main peculiarities of young people's communicative behavior in social networks are defined by the fact that cyberspace changes dynamic parameters of communicative behavior, both through their intensification, and by means of transition from communication in small groups to communication in big groups.

As a basic difference of a small group in social networks from a small group in objective reality serves borders permeability. Objective reality small group has steady borders, it includes certain subjects which take certain roles. As for the social networks small group, its composition can constantly be changed and transformed on the terms of personal anonymity, roles in group can also be redistributed anonymously. The next difference is the small groups adjustability (not spontaneous nature of appearance, submission to formal rules). Small groups in social networks are formed, mainly, spontaneously (See Table 3). 
Table 2: The comparative analysis of small groups in social networks and in the reality not mediated by technical means

\begin{tabular}{|c|c|c|}
\hline Indicator & $\begin{array}{l}\text { Small group in objective } \\
\text { reality }\end{array}$ & Small group in social networks \\
\hline Group size & From 3 to 20 & From 3 to 40 \\
\hline Unifying component & $\begin{array}{l}\text { General-purpose } \\
\text { work }\end{array}$ & $\begin{array}{l}\text { General point of communication (chat, } \\
\text { group, media content) }\end{array}$ \\
\hline Personal contact & Yes & Yes, but probably no \\
\hline Emotional relationships & Yes & Yes, but probably no \\
\hline Group norms & Yes & Yes, but probably no \\
\hline Typical example & Family, training group & $\begin{array}{l}\text { Chat in private messages, chat in } \\
\text { comments, special interest group }\end{array}$ \\
\hline Time stability & $\begin{array}{l}\text { Stable. Existence on the } \\
\text { formal bases is possible. }\end{array}$ & Unstable \\
\hline
\end{tabular}

Membership in a small group of social networks has no objective definiteness as the person who just observes correspondence but does not enter it - will also be a member of a small group.

Communication in big groups in cyberspace and in the reality, which is not mediated by technical means also has essential differences (See Tab. 4).

Table 3: The comparative analysis of big groups in social networks and in the reality not mediated by technical means

\begin{tabular}{lll}
\hline Indicator & Big group in objective reality & Big group in social networks \\
\hline $\begin{array}{l}\text { Group size } \\
\text { Unifying factors }\end{array}$ & $\begin{array}{l}\text { Unlimited } \\
\begin{array}{l}\text { Formalized values, standards of } \\
\text { behavior and social and regulatory } \\
\text { mechanisms }\end{array}\end{array}$ & $\begin{array}{l}\text { Unlimited } \\
\text { Interest in the acquisition of specific } \\
\text { thematic content }\end{array}$ \\
Yes & $\begin{array}{l}\text { Coincide with the moral standards (not } \\
\text { to offend, not to "flood", etc.). Typical } \\
\text { for all the groups. }\end{array}$ \\
Typical example & $\begin{array}{l}\text { Parties, ethnic groups, production } \\
\text { and industry and public } \\
\text { organizations }\end{array}$ & $\begin{array}{l}\text { Groups with the average daily coverage } \\
\text { of } 7500 \text { people. }\end{array}$ \\
\hline
\end{tabular}

Out of the reality mediated by technical means, one person is the representative of one ethnic group, is a citizen of one country (even if he has several citizenships, he still lives in one country), is a member of one political party, etc. In social networks a person is able to form the profile in such a way that he can be listed in any ethnic group, any party, any country, even without being its real representative; as for big groups in social networks, a person can be the participant of infinite number of big groups, beginning from the fact that he can use all the existing social networks, and ending with the fact that he can be the participant of the infinite great number of special interest groups. Big groups in cyberspace are minimally formalized, maximally anonymous, and unstable (both due to their 
structure and existence duration). And these peculiarities are necessary to be correlated with the fact that the communicative activity in cyberspace moves to big groups more and more.

A big group on social network can change extremely quickly both according to its external signs, on the composition of the members and on the proclaimed purposes, values, and rules. For example, a group of fans can in one day replace completely all the content and become a radical extremist political group. Big groups on social networks, as well as groups in not mediated reality, have social regulation, they are subordinated to administrators, moderators, curators, support service, etc. which regulate rules implementation in group space. Stable social networks big groups, as well as big groups of not mediated reality, have group aspirations and feelings; carry out promotion, inducing the members of the group to certain valuable orientations and actions, have their own history, typical unique features, specific group roles and have public consciousness.

Measurement of communicative activity dynamic indicators in cyberspace, for example the frequency and the nature of information update in the author's account allow to diagnose not only the influence of each specific member on the community, but also the influence of the community on him.

\subsection{Analysis of Social User's accounts}

Social networks users' accounts were analyzed according to the following parameters: the number of posts and reposts on the wall; the number of marks "like" (likes); the number of messages and responses to messages; the number of comments in all the categories; the number of the used Internet memes in communication; the amount of information about the user in a social network's profile; closed or open social network profile; statistics of a user's social network profile; active time in network a day, a week (See table 4).

Table 4: Dynamic parameters of communicative behavior in social networks

\begin{tabular}{|c|c|c|c|c|}
\hline & Parameter & $\begin{array}{l}\text { Unit of } \\
\text { measurement }\end{array}$ & Description & $\begin{array}{l}\text { Measurement } \\
\text { procedure }\end{array}$ \\
\hline 1 & $\begin{array}{l}\text { The number of } \\
\text { posts on the } \\
\text { wall }\end{array}$ & $\begin{array}{l}\text { On a monthly } \\
\text { average }\end{array}$ & $\begin{array}{l}\text { Post is a communicative message } \\
\text { from one user to other users }\end{array}$ & $\begin{array}{l}\text { The analytical } \\
\text { review of a social } \\
\text { network } \\
\text { profile }\end{array}$ \\
\hline 2 & $\begin{array}{l}\text { The number of } \\
\text { reposts on the } \\
\text { wall }\end{array}$ & $\begin{array}{l}\text { On a monthly } \\
\text { average }\end{array}$ & $\begin{array}{l}\text { Repost reflects interests and user's } \\
\text { thematic preferences. If there are } \\
\text { more reposts, than posts, then } \\
\text { these are the indicators of } \\
\text { communicative passivity. }\end{array}$ & $\begin{array}{l}\text { The analytical } \\
\text { review of a social } \\
\text { network user' } \\
\text { profile }\end{array}$ \\
\hline 3 & $\begin{array}{l}\text { The number of } \\
\text { "like" marks in } \\
\text { all the } \\
\text { categories }\end{array}$ & $\begin{array}{l}\text { On a monthly } \\
\text { average }\end{array}$ & $\begin{array}{l}\text { The mark "like" acts as a form of } \\
\text { user's approval and also can be an } \\
\text { attempt of attraction of other user's } \\
\text { attention to oneself }\end{array}$ & $\begin{array}{l}\text { User survey } \\
\text { (information is } \\
\text { available only to the } \\
\text { user) }\end{array}$ \\
\hline
\end{tabular}


4 The number of messages and responses to the messages

5 The number of comments in all the categories

6 The number of Internet memes used in communication

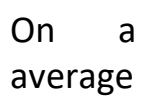

On a average

On a monthly average

On a monthly average

\section{daily}

The user is either an active initiator of communicative contacts, or a passive respondent

A comment reflects user's readiness to enter a dialogue or a discussion of a specific post.

Internet meme is visual reflection of verbal information. Where the person cannot express his thought with a word, he uses a meme.

User

survey

(information is

available only to the user)

User survey

(information is

available only to the user)

User's survey, analysis of comments in open "communities"

(information is available only to the user)

7 Amount of Does not The transfer of all the data about The analytical review of a social network user' profile in a social network profile correspond to the user into a social network the individual; profile reflects the readiness of the detailed user's personality for interaction on compressed. the terms of full disclosure.

8 Closed or open The profile is Readiness to show information closed, or the social network profile profile is open

9 Profile statistics

Audience of social coverage; page network user visitors; subscriptions and unsubscriptions; user's activity

10 Active time in In actual values the network a in hours and day, a week minutes a day, in average values a about oneself only to the chosen circle of "friends" or all social network users.

The given statistics reflects the

The analytical review of a social network user' profile

The analysis of page statistics

(information is with other social network users; what response is caused by his actions, comments, posts and available only to the user) reposts.

The indicator reflects general The analytical communicative inclusiveness and review of a social activity network user' profile week

According to each of the studied "open" accounts of social networks users its openness closeness and also amount of information about the user was analyzed. In this case the information realism was estimated (compliance to the information provided in a profile to the real individual's name, age, place of residence, etc.). According to the criterion of openness - closeness of a profile the degree of availability of the placed information to other users (for whom information is open - for all the users or only for "friends") was considered. 
The statistical analysis of the user's profile was carried out further: audience coverage (how many subscribers the account has); page visitors (the number of page visitors in different time intervals - a day, a week, a month); subscriptions and unsubscriptions (how many users subscribed and how many of them unsubscribed from the analyzed account); user's activity (how often user stays in the account, with what frequency). Also, the active time spent by the account user in social network a day and a week was calculated. For this purpose, the time (in hours and minutes) the user spent in social network in a 24-hour time interval; and also, the average time spent by the social network user a week was calculated.

Calculation of the posts and sent reposts placed by the social networks user in in his account was carried out on a monthly average (the monthly quantity of the placed posts and reposts in the last six months' time interval was summarized, and then the average month value was calculated). The number of likes and Internet memes was also calculated as average number a month (in the last six months' time interval). At the same time, the quantity of given and the quantity of the received likes and Internet memes by each user whose account participated in the investigation was analyzed separately.

The indicator of messages number was analyzed on a daily average (in the last month time interval). At the same time the differentiation by the number of the sent messages and the number of the messages received by the user of the account was carried out. The indicator of the average monthly number of comments was also calculated in the last six months' time interval. This indicator was differentiated by the number of the given and received comments. At the same time in the calculation procedure only primary comments given or received by the user in the response to the placed posts and reposts and also other information regardless of its form were considered (text, video or photo information, audio files).

The investigations analysis on the given issue allowed the authors to single out the main dynamic parameters of communicative behavior in social networks (See Table 4) and to use them as criteria for the communicative behavior analysis of the investigation participants in cyberspace.

\subsection{Results of survey}

The active time spent by the users of the studied age group in social networks a day is on average 6 hours 42 minutes. Distributing the specified time volume, a day, it is established that mainly social networks users are in cyberspace in two-time intervals: working hours from 10:00 till 15:00 and at night - from 22:30 till 4:40 o'clock (See Figure 1). 


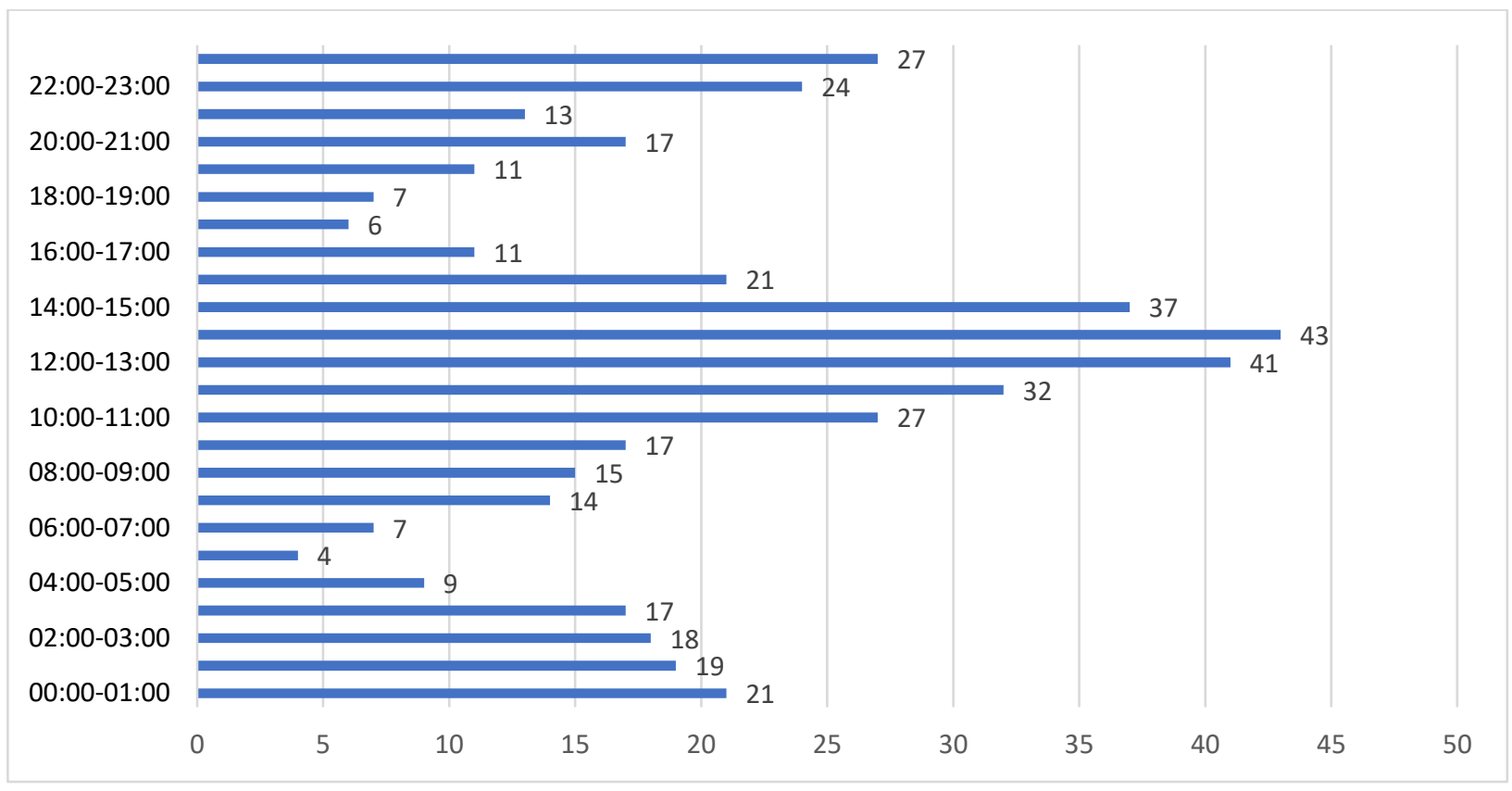

Figure 1. The number of the users who are online during the specified time period

Analyzing the active time spent by the users in social networks during a week the following regularity is determined (See Figure 2): according to the days of the week the maximum activity is revealed on Monday, Thursday and Friday (the average time spent in cyberspace is 7 hours 22 minutes a day); minimum - at the weekend (on Saturday and Sunday the average time of stay in cyberspace is 4 hours 54 minutes, mainly at night - up to $80 \%$ of the general time spent in social networks during weekend).

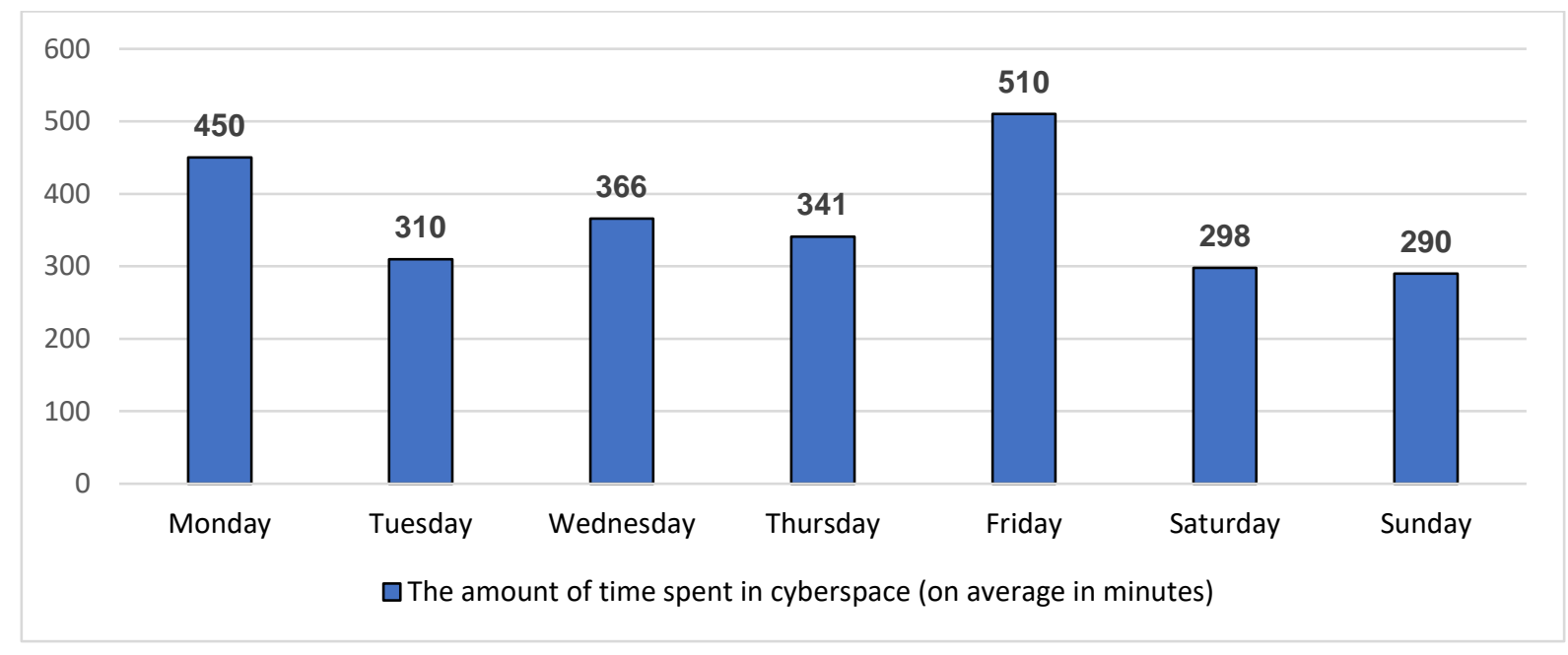

Figure 2. The histogram of average values indicators of the active time spent by users in social networks during a week 
The obtained results demonstrate that social networks users show maximum activity in working hours that indicates decrease (or absence) of working and personal hours differentiations. Social networks act as an active transponder of topical news, entertaining content and communication source that reduces relevance of the events in the surrounding space. Considering social networks as the main source of news information, on the one hand, the value of primary sources decreases on the other hand, its distortion takes place (perception of information happens through the value judgments of other users).

According to the indicator of the profile's openness - closeness it is established that the more senior the social networks users are, the more often they close their pages. The number of the closed social networks users' pages at the age of $18-22$ years old is $34.8 \%$; at the age of $23-25$ years old $-54.9 \%$. The desire to close a profile is connected with the fears of fraud (use of someone else's photos, creation of fake pages, breaking of accounts for the purpose of receiving money and so forth) and increase in the number of haters (users who attack the account owner with harsh criticism and overt negative). The indicator of profile's openness - closeness characterizes users' communicative selectivity. Closing the profile, making it available to viewing only to a limited circle of other users, the owner limits the circle of communicative contacts in social networks.

The indicator of the amount of information about the user in social network profile is characterized by the transfer of all the data about the user into the social network's profile reflects readiness of the user's individual for interaction on the terms of full disclosure. As a result of the investigation two peculiarities are revealed: first, the younger the user is, the more detailed information he presents in the profile. Secondly, the more active the page is and the more subscribers and visitors the page has, the more detailed information is specified about the owner of the page. At the same time, it is also necessary to note the presence of contradictory personal information about the profile's owner (it is revealed in case of $7.8 \%$ of the studied users' accounts). It is possible to assume that in this case the availability of personal information of opposite (or contradictory) content indicates the discrepancy to a real subject (individual). The amount of information about the user in a profile characterizes manifestation of differentiation of its virtual identity. The more information is in a profile, the higher the differentiation of its virtual identity manifestation. Respectively, the higher the differentiation of virtual identity, the higher the probability of its compliance with real identity in objective space.

As a result of the investigation, it is established that the number of the posts posted on users' wall in social networks on average is $44.5 \pm 9.35$ a month. The average number of the reposts posted on the wall in social networks is $77.2 \pm 12.83$ a month (See Figure 3 ). 
The number of reposts on the wall

The number of "like" marks (likes)

The number of comments in all the categories

The number of Internet-memes used in communication

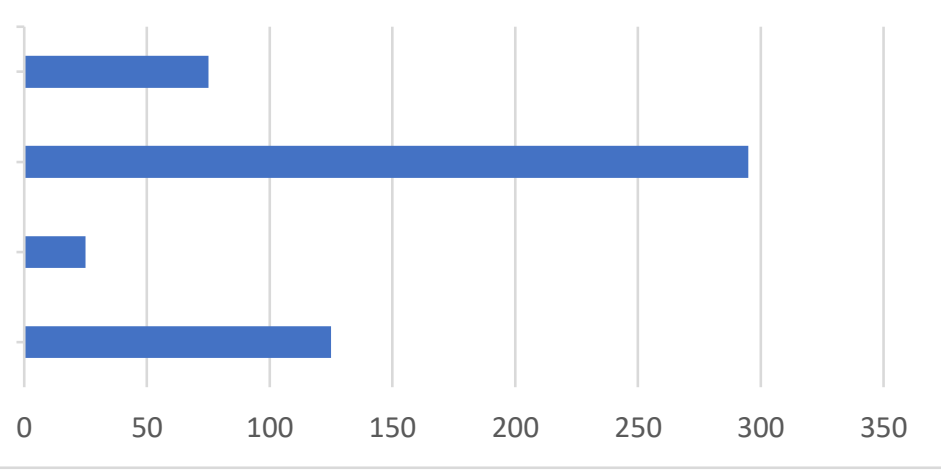

Figure 3. The histogram of indicators of average values (a month) dynamic parameters of communicative behavior of the youth in social networks

At the same time, for example, the social network VKontakte imposes a limit for the number of reposts - no more than 150 on one page daily. In case of excess of this limit the user's page is blocked by automatic algorithms. The number of users' posts and reposts in social networks characterizes readiness to share important (according to the user) information for the purpose of receiving social approval. Almost double quantity prevalence of the placed reposts over the quantity of the placed posts demonstrates that users share "someone else's" information and news than their personal information more willingly. At the same time the prevalence of acts of relaying of information (repost) over the acts of broadcast of information (post) by the user indicates the desire and maintenance of passive inclusiveness in the group, forms, characteristic of network communication.

If we consider the number of marks "like" (so-called likes), acting as a form of approval of the user or attempt of attraction to themselves the attention of another user, it is established that on average one active user gives $295.3 \pm 27.86$ likes a month. At the same time, most often these marks are given to relatively personal information of the user placed in public access (personal photos and video materials, personal stories, representation of own experience). Giving likes in social networks acts as one of the most available and safe forms of social approval expression because of its unambiguity. In the process of giving likes by social networks users there is no opportunity to be misunderstood (that is not excluded in the addition of comments and memes). One more advantage of "likes" usage is the minimality of time expenses and efforts (unlike comments and memes). And their quantity allows to maintain one's demand and popularity in virtual communicative space.

Estimating comments and Internet memes left by social networks users in all the categories, it is established that the average number of comments $(27.4 \pm 3.18)$ is significantly less than the number of Internet memes (122.1 \pm 12.64$)$. A meme represents the cultural unit in the communicative platform characterizing visualization of a joke or mockery over some significant event by means of familiar images or text out gaming. This fact can be explained by the idea that comments writing demands the formation of the answer verbally, connected with the need of construction of an emotional and cognitive reaction component of the person that is labor-intensive, and it is not always possible to be carried out. As for memes: there are certain stable and clear to all (to most of users) memes characterizing (reflecting) this or that response to the comment or a post. Thus, memes represent ready known reaction models. The usage of memes most often is a necessary condition of maintenance of high pages activity of social networks users. At the same time memes are not always positive. Analyzing the used Internet memes 
in social networks user's communication, it is established that in most cases they are characterized by ambiguity: have the playing a trick character ( $49.4 \%$ of used Internet memes of the analyzed accounts). The share of positive and approving Internet memes in communication of social networks users makes $29.2 \%$; negative (humiliating and disapproving) $-21.4 \%$.

Comments and memes are also manifestations of a form of social approval in cyberspace. However, their number is significantly less than the number of likes given by users. Unlike likes (allowing to express only the positive relation to the placed information), memes and comments also allow to give negative assessment. Placement of comments, besides emotional assessment also allows to provide substantial assessment of information placed by the user (as visual in the form of a photo, video images, and in the form of information messages).

The analysis of the number of messages and responses to them allowed to single out the fact that $57.2 \%$ of social networks users are active initiators of communicative contacts, initiating the process of communication in cyberspace (on average the number of messages exceeds the number of responses four times). At the same time $31.2 \%$ of the messages initiating communication are depersonalized. Passive respondents, as a rule, are the social networks users of more senior age having a large number of subscribers and showing high selectivity concerning those with whom to enter active communication in cyberspace, and with whom - no. The number of messages characterizes the social networks users' communicative activity and also readiness to join new social interactions, or to support already existing ones.

For the assessment of social networks users' integration degree in the communicative process in cyberspace correlation analysis of the parameters characterizing active communicative behavior (the number of the exposed posts and reposts, number of given likes, the number of sent messages, the number of sent responses to the messages, the number of the left comments and memes), and the parameters characterizing passive communicative behavior (the number of the received reposts, the number of the received likes, the number of the received messages, the number of the received responses to messages, the number of the received comments and memes) of social networks users was carried out ( $r$-criterion of Spearman rank correlation, r.0.05).

As a result of the correlation analysis, it is established that the more posts the user places in his profile, the bigger is the number of reposts sent to him by other users $(r=0.54)$ (See Figure 4). 
Parameters of active communicative behavior:
Parameters of passive communicative behavior:

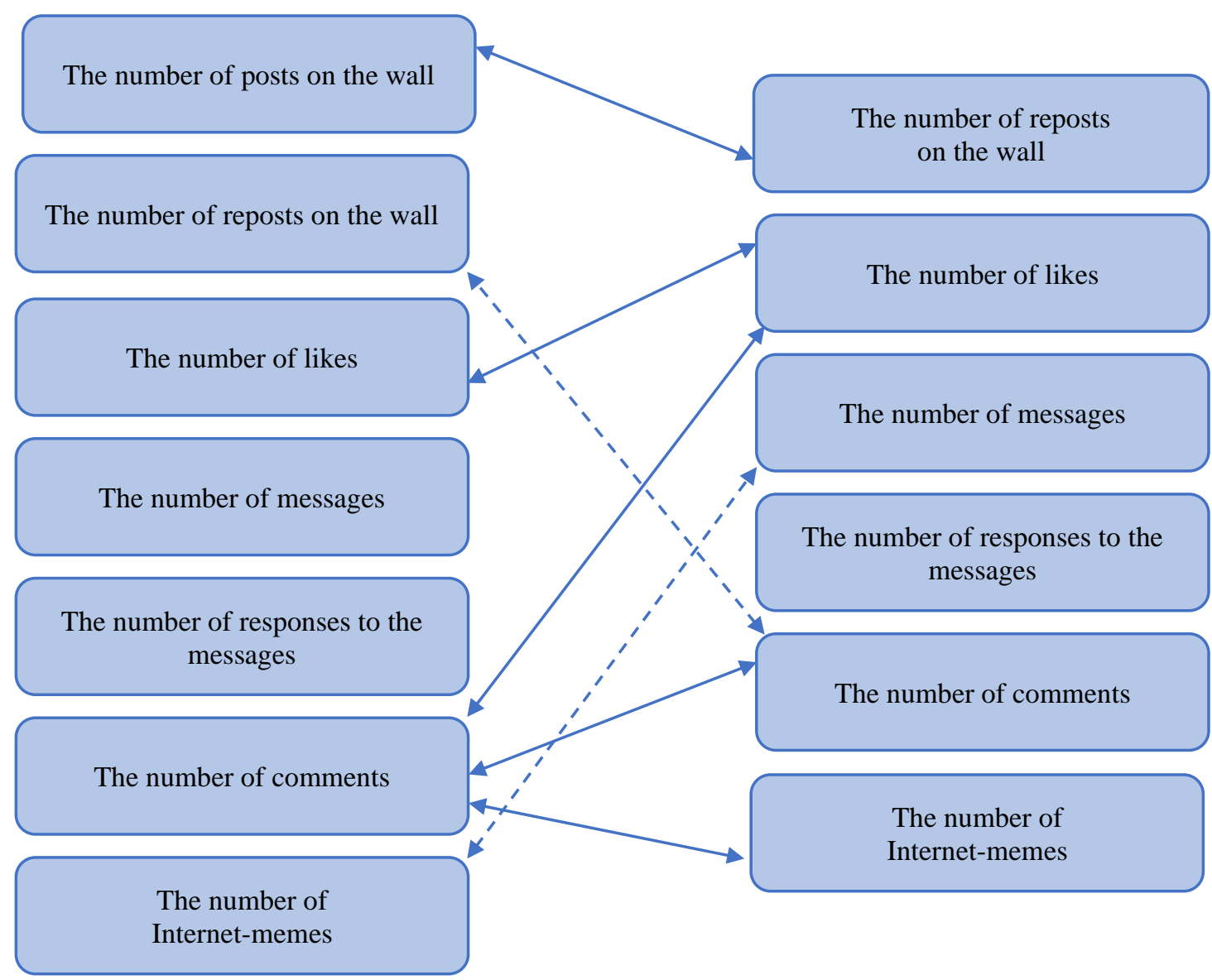

Figure 4. The system of parameters interrelations characterizing active communicative behavior and the parameters characterizing passive communicative behavior of social networks users (the solid line indicates positive correlation, dotted line - negative correlation)

Concerning the sent reposts the reverse trend is revealed: the more reposts the social network user sends, the less comments he receives $(r=-0.49)$. Directly proportional statistically significant interrelation is revealed between the number of the comments left by the user and the number of likes $(r=0.52)$, comments $(r=0.62)$ and memes $(r=0.64)$ received by him. The more comments the user gives, the more likes, memes, and responses he receives. Between the number of the given memes and the number of the received messages the inversely proportional interrelation is revealed $(r=-0.55)$ : the less memes are sent by the user, the bigger number of messages he receives. At the same time, the contents of the received messages often reflect misunderstanding of that meme which was sent and the purpose of these messages sending is receiving additional explanations. 
The analysis of dynamic characteristics of communicative behavior of the youth in social networks indicates the communication vector shift from small to big groups. The behavior activity (inclusiveness) is aimed at the involvement of participants with recipient position (i.e., the participants accepting communication of the communication initiator). The volume of the transmitted information is significantly more than the volume of the accepted information. The request for no personified information adoption which is generalized by the opinion estimated by quantity of likes, etc. is distinctly fixed (Boz, 2018; Al Hashimi, Mahdi, Al Muwali \& Zaki, 2019).

One more specific feature of communicative behavior in social networks in dynamic aspect is the mechanism of management of information flows direction. In the reality which is not mediated by technical means streamlining of communicative streams is regulated via mechanisms of communicative roles distribution. In social networks, the reverse regularity is observed: regulation and streamlining of the communicative streams forming communicative networks is carried out through the activity of the subject's account. The higher the activity of the user's account (the more subscribers, page visitors, comments, messages, etc.), the higher his position in status and role hierarchy of the group. In this regard the innovative functionality of social networks becomes the catalyst of frequency of communicative acts of any quality and sign.

Generally positive influence on the dynamics of communicative behavior in social networks of active communicative behavior itself is found: the higher is the activity of the account owner (more intensive parameters of active communicative behavior) - the higher is the subscribers' or casual recipients' feedback (more intensive parameters of passive communicative behavior). Such form of active communicative behavior as comments, connected with high response according to three parameters of passive communicative behavior turns out to have high level of impact: likes, comments and memes (Bello, Idris \& Bappayo, 2020).

Not numerous selections can be considered as the restriction of this investigation, at the same time, the sufficient uniformity of the results obtained from the respondents living in remoted from each other settlements allow to speak about their basic importance.

\section{Conclusion}

Communicative behavior gains characteristics of high dynamism in the context of big social groups. It is possible to assume that it occurs due to the lack of the personified targeting of communicative behavior acts, and therefore, the removal of the critical aspect connected with specific features of the addressee. At the same time the way of nonverbal communication (memes, likes, etc.) is also transformed towards the unification of cognitions - models clear to the maximum large number of communication participants. This trend a priori simplifies the semantic content of communication, reducing the level of communication intellectuality. At the same time, similar communication causes the possibility of manipulation over the communicants aiming to assert themselves in a big group that increases the vulnerability of their social adaptation. The usage of the main dynamic parameters of communicative behavior in social networks as criteria for the analysis of communicative behavior of the participants of the research in cyberspace allows not only to create a portrait of the typical communicant of cyberspace, but also to predict the potential strategy of his behavior. 
The results of communicative behavior parameters obtained in the process of the research are possible to be used for the creation of an expert system on the basis of neural network. The database within such a system is capable to trace communication indicators in big groups and to define sources of formal and dynamic activity, combining with indicators of communication semantics. This expert system can be used for the assessment of social interaction of an object, determination of "toxicity" of his communication and social danger to society.

Within the further investigations the identification of age regularities of dynamic parameters of communicative behavior in different age groups, and also the research of substantial (semantic) parameters of communicative behavior of social networks users seems to be perspective.

\section{References}

Al Hashimi, S., Mahdi, N., Al Muwali, A., \& Zaki, Y. (2019). Proposing a framework for evaluating digital creativity in social media and multimedia-based art and design education. Global Journal of Arts Education, 9(2), 4862. https://doi.org/10.18844/giae.v9i2.4238

Allen, C. (1996). What's wrong with the "Golden Rule"? Conundrums of conducting ethical research in cyberspace. The Information Society, 12(2), 175-188. https://doi.org/10.1080/713856146

Allison, K.R. \& Bussey, K. (2017). Individual and collective moral influences on intervention in cyberbullying. Computers in Human Behavior, 74, 7-15. https://doi.org/10.1016/i.chb.2017.04.019

Alun, J.R. (1994). The ethics of research in cyberspace. Internet Research, 4(3), 30-35. https://doi.org/10.1108/10662249410798894

Andreassen, C.S., Torsheim, T., Brunborg, G.S. \& Pallesen, S. (2012). Development of a Facebook addiction scale. Psychological Reports, 110(2), 501-517. https://doi.org/10.2466/02.09.18.PR0.110.2.501-517

Arfini, S., Bertolotti, T. \& Magnani, L. (2019). Online communities as virtual cognitive niches. Synthese, 196(1), 377-397. https://doi.org/10.1007/s11229-017-1482-0

Bargh, J.A. \& McKenna, K.Y.A. (2004). The Internet and social life. Annual Review of Psychology, 55(1), 573-590. https://doi.org/10.1146/annurev.psych.55.090902.141922

Baryshev, R. (2008). Personality in the context of ciberspace. Bulletin of Chelyabinsk State University, 217, 155-18. URL: https://elibrary.ru/item.asp?id=15638563

Batty, M. \& Barr, B. (1994). The electronic frontier: Exploring and mapping cyberspace. Futures, 26(7), 699-712. https://doi.org/10.1016/0016-3287(94)90039-6

Baumgartner, S.E., Sumter, S.R., Peter, J. \& Valkenburg, P.M. (2015). Sexual self-presentation on social network sites: Who does it and how is it perceived? Computers in Human Behavior, 50, 91-100. https://doi.org/10.1016/i.chb.2015.03.061

Bayanova, A.R., Kuznetsov, V.V., Merculova, L.V., Gorbunova, L.N., Pervozvanskaya, O.A., Shalamova, O.O. \& Vorobyova, C.I. (2019). Student Performance Interrelation With Gadget Use At Lessons. Journal of $\begin{array}{llll}\text { Environmental Treatment } & \text { Techniques, }\end{array}$ http://www.jett.dormaj.com/docs/Volume7/Issue\%203/Student\%20Performance\%20Interrelation\%20wi th\%20Gadget\%20Use\%20at\%20Lessons.pdf 

Journal on Educational Technology: Current Issues. 13(4), 863-889. https://doi.org/10.18844/wjet.v13i4.6272

Bayanova, A.R., Sivova, I.V., Kamasheva, Y.L., Popova, O.V., Semyanov, E.V., Shagieva R.V. \& Yusupov, I.M. (2020). Student online services consumption: Routine practices or mistrust to digital service? Contemporary Educational Technology, 11(1), 47-54. https://eric.ed.gov/?id=EJ1234836

Bello, H. S., Idris, S. U., \& Bappayo, A. (2020). Media and educational technology in Nigeria: Managing the broadcast programmes of Radio Nigeria Globe FM towards girl child education. International Journal of Innovative Research in Education, 7(1), 16-25. https://doi.org/10.18844/ijire.v7i1.4715

Berghel, H. \& Hal, A. (1997). Cyberspace 2000: dealing with information overload. Communications of the ACM, 40(2), 19-24. https://doi.org/10.1145/253671.253680

Biocca, F. (2006). The cyborg's dilemma: Progressive embodiment in virtual environments. Journal of ComputerMediated Communication, 3(2), 1-10. https://doi.org/10.1111/j.1083-6101.1997.tb00070.x

Birch, D. \& Young, M.A. (1997). Financial services and the Internet - What do cyberspace mean for the financial services industry? Internet Research, 7(2), 120-128. https://doi.org/10.1108/10662249710165262

Bondarenko, S.V. (2004). Social structure of virtual network communities. Rostov na Dony: Rostov State University.

Boz, H. (2018). Social relationship network and communication at old age. Cypriot Journal of Educational Sciences, 13(1), 81-93. https://doi.org/10.18844/cjes.v13i1.3371

Branscomb, A.W. (1994). Who owns information? From privacy to public access. New York: Basic books. https://dl.acm.org/doi/abs/10.5555/191422

Buffardi, L.E. \& Campbell, W.K. (2008). Narcissism and social networking web sites. Personality and Social Psychology Bulletin, 34(10), 1303-1314. https://doi.org/10.1177/0146167208320061

Cheung, C.M.K., Chiu, P.-Y. \& Lee, M.K.O. (2011). Online social networks: Why do students use facebook? Computers in Human Behavior, 27(4), 1337-1343. https://doi.org/10.1016/J.CHB.2010.07.028

Cooper, A. \& Sportolari, L. (1997). Romance in cyberspace: Understanding online attraction. PsycNET. Journal of $\begin{array}{lllll}\text { Sex Education } \quad \text { \& } & \text { Therapy, }\end{array}$ https://www.tandfonline.com/doi/abs/10.1080/01614576.1997.11074165

Correa, T., Hinsley, A.W. \& de Zúñiga, H.G. (2010). Who interacts on the Web? The intersection of users' personality and social media use. Computers in Human Behavior, 26(2), 247-253. https://www.sciencedirect.com/science/article/pii/S0747563209001472

Dahlqvist, H.Z., Landstedt, E., Young, R. \& Gadin, K.G. (2016). Dimensions of peer sexual harassment victimization and depressive symptoms in adolescence: A longitudinal cross-lagged study in a Swedish sample. Journal of Youth and Adolescence, 45(5), 858-873. https://doi.org/10.1007/s10964-016-0446-x

Danilova, O.A., \& Kondratyeva, I.G. (2019). Self-education of studying youth: historical aspect. Vestnik NTsBZhD, 2(40), 19-26.

Digital. (2019). Global Internet Use Accelerates. URL: https://wearesocial.com/blog/2019/01/digital-2019-globalinternet-use-accelerates

Dishon, G. \& Ben-Porath, S. (2018). Don't @ me: Rethinking digital civility online and in school. Learning, Media, and Technology, 43(4), 434-450. https://doi.org/10.1080/17439884.2018.1498353

Drozdikova-Zaripova, A.R., \& Davlieva, E.R. (2019). Specificity and causes of computer addiction in adolescents attending additional education organizations. Vestnik NTSBGD, 3(41), 35-44.

Dumont, R.A. (1996). Teaching and learning in cyberspace. IEEE Transactions on Professional Communication, 39(4), 192-204. https://doi.org/10.1109/47.544575 
Nikishina, V.B., Sokolskaya, M.V., Musatova, O.A., Zapesotskaya, I.V., Danilova, A.V.\& Balykina, A.M. (2021). Type the title of your paper. World Journal on Educational Technology: Current Issues. 13(4), 863-889. https://doi.org/10.18844/wjet.v13i4.6272

Durkin, K.F. \& Bryant, C.D. (1995). "Log on to sex": Some notes on the carnal computer and erotic cyberspace as an emerging research frontier. Deviant Behavior, 16(3), 179-200. https://doi.org/10.1080/01639625.1995.9967998

Errasti, J., Amigo, I. \& Villadangos, M. (2017). Emotional uses of Facebook and Twitter: Its relationship with empathy, narcissism, and self-esteem in adolescence. Psychological Reports, 120(6), 997-1018. https://doi.org/10.1177/0033294117713496

Festl, R. \& Quandt, T. (2016). The role of online communication in long-term cyberbullying involvement among girls and boys. Journal of Youth and Adolescence, 45(9), 1931-1945. https://doi.org/10.1007/s10964-016$\underline{0552-9}$

Festl, R., Reer, F. \& Quandt, T. (2019). Online sexual engagement and psychosocial well-being: The mediating role of sexual victimization experiences. Computers in Human Behavior, 98, 102-110. https://doi.org/10.1016/j.chb.2019.04.010

Fogel, J. \& Nehmad, E. (2009). Internet social network communities: Risk taking, trust, and privacy concerns. Computers in Human Behavior, 25(1), 153-160. https://doi.org/10.1016/J.CHB.2008.08.006

Forest, A.L. \& Wood, J.V. (2012). When Social Networking Is Not Working? Psychological Science, 23(3), 295-302. https://doi.org/10.1177/0956797611429709

Froehling, O. (1997). The Cyberspace "War of Ink and Internet" in Chiapas, Mexico. Geographical Review, 87(2), 291. https://doi.org/10.2307/216010

Galchenko, N.A., Shatskaya, I.I., Makarova, E.V., Kulesh, E.V., Nizamutdinova, S.M., Yudina, A.M. \& Skutelnik, O.A. (2020). Student hood spiritual needs in self-isolation period: Features and ways to meet them. EurAsian Journal of BioSciences, 14(1), 2229-2234. http://ejobios.org/download/student-hood-spiritual-needs-inself-isolation-period-features-and-ways-to-meet-them-7769.pdf

Galiullina, E.R. (2018). Mastering the methods of generating ideas as a way to develop creativity. Vestnik NTSBGD, $1(35), 12-15$.

Gillath, O., Karantzas, G. \& Lee, J. (2019). Attachment and social networks. Current Opinion in Psychology, 25, 2125. https://doi.org/10.1016/i.copsyc.2018.02.010

Gimaliev, V.G., Prokopyev, A.I., Vershinin, V.P., Ivanova, M.E., Erkibaeva, G.G., Aytuganova, J.I., \& Alexandrova, N.S. (2020). Public Relations in Organizations in Student View: Accumulator of Management Tools or Formation of Partnership and Friendly Relations. Journal of environmental treatment techniques, 8(4), 1326-1330. https://tinyurl.com/vssman8i

GlobalWebIndex. (2019). Digital Analytics, Audience Insight Tools. URL: https://www.globalwebindex.com/ (Retrieved April 27, 2019).

Harasim, L. (1993). Collaborating in cyberspace: Using computer conferences as a group learning environment. Interactive Learning Environments, 3(2), 119-130. https://doi.org/10.1080/1049482930030202

Hinduja, S. \& Patchin, J.W. (2008). Personal information of adolescents on the Internet: A quantitative content analysis of MySpace. Journal of Adolescence, 31(1), 125-146. https://doi.org/10.1016/i.adolescence.2007.05.004

Hootsuite. (2019). Social Media Marketing. URL: https://hootsuite.com/ (Retrieved April 27, 2019).

Hu, J., Zhang, Q.-M. \& Zhou, T. (2019). Segregation in religion networks. EPJ Data Science, 8(1), 6-18. https://doi.org/10.1140/EPJDS/S13688-019-0184-X

Huang, C. (2019). Social network site use and big five personality traits: A meta-analysis. Computers in Human Behavior, 97, 280-290. https://doi.org/10.1016/i.chb.2019.03.009 

Journal on Educational Technology: Current Issues. 13(4), 863-889. https://doi.org/10.18844/wjet.v13i4.6272

Hughes, D.J., Rowe, M., Batey, M. \& Lee, A. (2012). A tale of two sites: Twitter vs. Facebook and the personality predictors of social media usage. Computers in Human Behavior, 28(2), 561-569. https://doi.org/10.1016/i.chb.2011.11.001

Jabbar, M. N., \& Hussin, F. (2019). Quality management as a strategic tool to enhance the relationship between leaders' behavior and lecturers' job satisfaction. International Journal of Current Innovations in Interdisiplinary Scientific Studies, 3(1), 01-15. https://un-pub.eu/ojs/index.php/IJ-CISS/article/view/5033

Jacobsen, W.C. \& Forste, R. (2011). The Wired generation: Academic and social outcomes of electronic media use among university students. Cyberpsychology, Behavior, and Social Networking, 14(5), 275-280. https://doi.org/10.1089/cyber.2010.0135

Jenks, C.J. (2019). Talking trolls into existence: On the floor management of trolling in online forums. Journal of Pragmatics, 143, 54-64. https://doi.org/10.1016/i.pragma.2019.02.006

Johnson, D.R. \& Post, D.G. (1996). Law and borders - the rise of law in cyberspace. Stanford Law Review, 48, 13671376. https://doi.org/10.2139/ssrn.535

Juvonen, J. \& Gross, E.F. (2008). Extending the school grounds? Bullying Experiences in Cyberspace. Journal of School Health, 78(9), 496-505. https://doi.org/10.1111/i.1746-1561.2008.00335.x

Kamalou, S., Shaughnessy, K. \& Moscovitch, D.A. (2019). Social anxiety in the digital age: The measurement and sequelae of online safety-seeking. Computers in Human Behavior, 90, 10-17. https://doi.org/10.1016/i.chb.2018.08.023

Keum, B.T. \& Miller, M.J. (2018). Racism on the Internet: Conceptualization and recommendations for research. Psychology of Violence, 8(6), 782-791. https://doi.org/10.1037/vio0000201

Khairullina, E.R., Shubovich, M.M., Bogdanova, V.I., Slepneva, E.V., Mashkin, N.A. \& Rodyukova, T.N. (2020). Modern student youth civic identity: Political activity or social responsibility? Opcion, 36(Special Edition 27), 1703-1717. https://dialnet.unirioja.es/servlet/articulo?codigo=7667451

King, S.A. (1996). Researching Internet Communities: Proposed ethical guidelines for the reporting of results. The Information Society, 12(2), 119-128. https://doi.org/10.1080/713856145

Krämer, N.C. \& Winter, S. (2008). Impression management 2.0. Journal of Media Psychology, 20(3), 106-116. https://doi.org/10.1027/1864-1105.20.3.106

Krishnan, S. (2016). Electronic warfare: A personality model of cyber incivility. Computers in Human Behavior, 64, 537-546. https://doi.org/10.1016/i.chb.2016.07.031

Kvon, G.M., Vaks, V.B., Kalimullin, A.M., Bayanova, A.R., Shaidullina, A.R., Dolzhikova, A.V. \& Lapidus, N.I. (2019). Developing the Informational and Digital Environment of a University: Problem Analysis and Assessment. Eurasia Journal of Mathematics, Science and Technology Education, 15(10), em1767. https://www.ejmste.com/article/developing-the-informational-and-digital-environment-of-a-universityproblem-analysis-and-assessment-7719

Larson, R.R. (1996). Bibliometrics of the World Wide Web: An exploratory analysis of the intellectual structure of cyberspace. In S. Hardin (Ed.), Proceedings of the 59th Annual Meeting, ASIS 96 (pp. 71-79). Medford: The American Society for Information Science by Information Today. https://sherlock.ischool.berkeley.edu/asis96/asis96.ps

Lessig, L. (1996). The Zones of Cyberspace. Stanford Law Review, 48(5), 1403. https://doi.org/10.2307/1229391

Levina, I.D., Ukolova, L.I., Lavrentyeva, E.Y., Akhilgova, M.T., Zharikov, Y.S., Popova, O.V., Semyanov, E.V., Malanov, I.A., Muskhanova, I.V., Magomeddibirova, Z.A. \& Bazaeva, F.U., Isaeva M.A. (2019). Nursing home conditions for elderly people and its peculiarities of their adaptation. EurAsian Journal of BioSciences, 13(2), 1549-1555. https://tinyurl.com/s85davju 

Journal on Educational Technology: Current Issues. 13(4), 863-889. https://doi.org/10.18844/wjet.v13i4.6272

Lin, K.-Y. \& Lu, H.-P. (2011). Why people use social networking sites: An empirical study integrating network externalities and motivation theory. Computers in Human Behavior, 27(3), 1152-1161. https://doi.org/10.1016/J.CHB.2010.12.009

Liu, D., Ainsworth, S.E. \& Baumeister, R.F. (2016). A Meta-Analysis of Social Networking Online and Social Capital. Review of General Psychology, 20(4), 369-391. https://doi.org/10.1037/gpr0000091

Maksyutova, N.N. (2019). Secondary vocational education in the context of informatization: problems and prospects. Vestnik NTSBGD, 4(42), 44-50.

Malinen, S. (2015). Understanding user participation in online communities: A systematic literature review of empirical studies. Computers in Human Behavior, 46, 228-238. https://doi.org/10.1016/i.chb.2015.01.004

Manago, A.M., Graham, M.B., Greenfield, P.M. \& Salimkhan, G. (2008). Self-presentation and gender on MySpace. Journal of Applied Developmental Psychology, 29(6), 446-458. https://doi.org/10.1016/j.appdev.2008.07.001

Manago, A.M., Taylor, T. \& Greenfield, P.M. (2012). Me and my 400 friends: The anatomy of college students' Facebook networks, their communication patterns, and well-being. Developmental Psychology, 48(2), 369380. https://doi.org/10.1037/a0026338

McKenna, K.Y.A. \& Bargh, J.A. (2000). Plan 9 from cyberspace: The Implications of the Internet for Personality and Social Psychology. Personality and Social Psychology Review, 4(1), 57-75. https://doi.org/10.1207/S15327957PSPR0401 6

McKenna, K.Y.A., Green, A.S. \& Gleason, M.E.J. (2002). Relationship formation on the Internet: What's the Big Attraction? Journal of Social Issues, 58(1), 9-31. https://doi.org/10.1111/1540-4560.00246

Mehdizadeh, S. (2010). Self-Presentation 2.0: Narcissism and self-esteem on Facebook. Cyberpsychology, Behavior, and Social Networking, 13(4), 357-364. https://doi.org/10.1089/cyber.2009.0257

Minakhmetova, A.Z., Skutelnik, O.A., Fedorchuk, Y.M., Shulga, T.I., Pavlushin, A.A., \& Shagiev, B.V. (2017). Motivational and valuable orientation of teachers as a condition to form students' tolerant behavior. Man in India, 97(3), 323-332. https://www.rea.ru/ru/org/managements/orgnirupr/Documents/49-s17.pdf

Montaner, S. (2020). EFL written competence through twitter in mobile version in compulsory secondary education. Global Journal of Foreign Language Teaching, 10(2), 101-110. https://doi.org/10.18844/giflt.v10i2.4665

Mukhametshin, R. Z., Kryukova, N. I., Beloborodova, A. V., Grinenko, A. V., \& Popova, O. V. (2019). Implementation of efficient energy policy in Russia: Energy consumption monitoring and problem analysis. International Journal of Energy Economics and Policy, 9(4), 224-232. http://www.zbw.eu/econisarchiv/bitstream/11159/4955/1/1743092741.pdf

Murase, Y., Jo, H.-H., Török, J., Kertész, J. \& Kaski, K. (2019). Structural transition in social networks: The role of homophily. Scientific Reports, 9(1), 4310. https://doi.org/10.1038/s41598-019-40990-z

Nadkarni, A. \& Hofmann, S.G. (2012). Why do people use Facebook? Personality and Individual Differences, 52(3), 243-249. https://doi.org/10.1016/i.paid.2011.11.007

Nosko, A., Wood, E. \& Molema, S. (2010). All about me: Disclosure in online social networking profiles: The case of Facebook. Computers in Human Behavior, 26(3), 406-418. https://doi.org/10.1016/j.chb.2009.11.012

Nurieva, N.S., \& Inozemtseva, K.M. (2020). Creative independence in the space of foreign language education as a means of developing student information culture. Vestnik NTSBGD, 4(42), 48-56.

O'Leary, S.D. (1996). Cyberspace as sacred space: Communicating religion on computer networks. Journal of the American Academy of Religion, 64(4), 781-808. https://doi.org/10.1093/iaarel/LXIV.4.781 

Journal on Educational Technology: Current Issues. 13(4), 863-889. https://doi.org/10.18844/wjet.v13i4.6272

Orekhovskaya, N. A., Chistyakov, A. A., Kryukova, N. I., Krokhina, J. A., Ospennikov, Y. V., \& Makarova, E. V. (2019). Orthodoxy and modernity their contact facets in Russian society. European Journal of Science and Theology, 15(2), 67-77. http://www.ejst.tuiasi.ro/Files/75/7 Orekhovskaya\%20et\%20al.pdf

Owan, V.J., Ekpe, M.B., \& Eneje, S. (2020). Undergraduates' Utilization of Social Networking Media and Sexual Behaviours in Higher Education: A Case Study. Pedagogical Research, 5(2), em0062. https://doi.org/10.29333/pr/7940

Parks, M.R. \& Floyd, K. (2006). Making friends in cyberspace. Journal of Computer-Mediated Communication, 1(4), 80-97. https://doi.org/10.1111/i.1083-6101.1996.tb00176.x

Patchin, J.W. \& Hinduja, S. (2006). Bullies move beyond the schoolyard. Youth Violence and Juvenile Justice, 4(2), 148-169. https://doi.org/10.1177/1541204006286288

Pempek, T.A., Yermolayeva, Y.A. \& Calvert, S.L. (2009). College students' social networking experiences on Facebook. Journal of Applied Developmental Psychology, 30(3), 227-238. https://doi.org/10.1016/J.APPDEV.2008.12.010

Pervushina, V., Savushkin, L. \& Khutorskoi, C. (2017). Peculiarities of communication in kiberspace. Vestnik Voronezhskogo Gosudarstvennogo Universiteta. Seriya Filosofia, 1(23), 59-71. URL: https://elibrary.ru/item.asp?id=29112121

Piralova, O.F., Gerasimenko, S.A., Kuznetsov, V.V., Popova, O.V., Subbotin, G.V., Kolomyts, O.G., \& Mashkin, N.A. (2020). Gaming Industry Trends in new Generation Specialist Training in University Environment. Journal of Environmental Treatment Techniques, 8(3), 1132-1135. https://tinyurl.com/u3y8bkc

Privalova, I.V., Shaidullina, A.R., Zheltukhina, M.R., Grinberg, T.E. \& Caselles, C.G. (2019). Coerced loss of national colorings - Linguistic issues of virtual team communication. XLinguae, 12(1), 151-164. https://doi.org/10.18355/XL.2019.12.01.12 DOI: 10.18355/XL.2019.12.01.12

Razumovskaya, M., Zaitseva, N.A., Larionova, A.A., Chudnovskiy, A.D. \& Breusova, E.A. (2018). Prospects for applying various forms of organizational integration to improve the quality of education. Astra Salvensis, 6 , 348-362. https://www.ceeol.com/search/article-detail?id=681325

Razumovskaya, M.I., Larionova, A.A., Zaitseva, N.A., Petrina, O.A, Vinogradova, M.V., Nagay, N.G. \& Takhumova, O.V. (2019). Models of Integrated Interactions Organization in the Field of Environmental Education. Journal of Environmental Treatment Techniques, 7(4), 576-580. https://tinyurl.com/xxud44n8

Riva, G. \& Galimberti, C. (1997). The psychology of cyberspace: A socio-cognitive framework to computermediated communication. New Ideas in Psychology, 15(2), 141-158. https://doi.org/10.1016/S0732$\underline{118 \times(97) 00015-9}$

Romkey, J. (1991). Whither cyberspace? Journal of the American society for information science, 42(8), 618-620.

Ross, C., Orr, E.S., Sisic, M., Arseneault, J.M., Simmering, M.G. \& Orr, R.R. (2009). Personality and motivations associated with Facebook use. Computers in Human Behavior, 25(2), 578-586. https://doi.org/10.1016/i.chb.2008.12.024

Rubio, G.L., Leskova, A., Prokopyev, A.I., Miroshkin, D.V. \& Kamneva, E.V. (2020). Despair or the loss of selfhood in Kierkegaard's sickness unto death. XLinguae, 13(3), 63-77. https://philpapers.org/rec/LEIDOT-3

Ryan, T. \& Xenos, S. (2011). Who uses Facebook? An investigation into the relationship between the Big Five, shyness, narcissism, loneliness, and Facebook usage. Computers in Human Behavior, 27(5), 1658-1664. URL: https://researchbank.rmit.edu.au/view/rmit:14934

Salakhova, V.B. \& Khabibullin, I.I. (2018). General scientific methodological principles. Simbirsk Scientific Journal Vestnik, 4(34), 36-42. 

Journal on Educational Technology: Current Issues. 13(4), 863-889. https://doi.org/10.18844/wjet.v13i4.6272

Salakhova, V.B. (2019). Improvement of the System for Prevention of Unsurveillance and Offenses in Minors in the Territory of Subjects of the Russian Federation. Simbirsk Scientific Journal Vestnik, 4(38), 59-71.

Sandel, T.L., Buttny, R. \& Varghese, M. (2019). Online interaction across three contexts: An analysis of culture and technological affordances. Journal of Intercultural Communication Research, 48(1), 52-71. https://doi.org/10.1080/17475759.2018.1552616

Seidman, G. (2013). Self-presentation and belonging on Facebook: How personality influences social media use and motivations. Personality and Individual Differences, 54(3), 402-407. https://doi.org/10.1016/J.PAID.2012.10.009

Shaidullina, A.R., Evsyukova, N.Y., Mikhailov, V.A., Gazizova, F.S., Masalimova, A.R., Khairullina, E.R. \& Galimzyanova, I.I. (2015). The curriculum project on professional and pedagogical teachers' communication culture formation. Mediterranean Journal of Social Sciences, 6(2S3), 202-208. DOI: 10.5901/mjss.2015.v6n2s3p202

Shirokova, O.V. (2019). Efficiency of human resources of state structures: role of standardization. Personality Formation, 3(4), 103-113.

Sinyagina, N.Yu. \& Artamonova, E.G. (2019). Successful future: education priorities. Personality Formation, 3(4), 10-17.

Subrahmanyam, K., Reich, S.M., Waechter, N. \& Espinoza, G. (2008). Online and offline social networks: Use of social networking sites by emerging adults. Journal of Applied Developmental Psychology, 29(6), 420-433. https://doi.org/10.1016/i.appdev.2008.07.003

Sudakova, Y.E., Kryukova, N.I., Yevgrafova, O.G., Derdizova, F.V., Aleksandrova, N.S. \& Shaidullina, A.R. (2017). Future teachers' communicative culture forming by means of drama-based pedagogy. Man in India, 97(14), 103-113. https://elibrary.ru/item.asp?id=31057245

Thach, L. \& Woodman, R.W. (1994). Organizational change and information technology: Managing on the edge of cyberspace. Organizational Dynamics, 23(1), 30-46. https://doi.org/10.1016/0090-2616(94)90086-8

Thomas, J. (1996). Introduction: A debate about the ethics of fair practices for collecting social science data in cyberspace. The Information Society, 12(2), 107-118. https://doi.org/10.1080/713856137

Valeeva, R.A., Baykova, O.V., Kusainov, A.K. (2016). Foreign language professional communicative competence as a component of the academic science teacher's professional competence. International Journal of Environmental and Science Education, 11(3), 173-183. URL: https://www.scopus.com/inward/record.uri?eid=2-s2.084959361858\&doi=10.12973\%2fijese. 2016.301 a\&partnerID $=40 \& \mathrm{md5}=4638 \mathrm{ff} 24 \mathrm{c} 2 \mathrm{e} 6480 \mathrm{f0} 90392606 \mathrm{f028}$ $\underline{\mathrm{d} 1 \mathrm{c}}$

Vogel, E.A. \& Rose, J.P. (2017). Perceptions of perfection: The influence of social media on interpersonal evaluations. Basic and Applied Social Psychology, 39(6), 317-325. https://doi.org/10.1080/01973533.2017.1356303

Vylkov, R.I. (2009). Cyberspace as a sociocultural phenomenon, a product of technological creativity and a projective idea: PhD Thesis. Ekaterinburg: Ural State University.

Wellman, B., Salaff, J., Dimitrova, D., Garton, L., Gulia, M. \& Haythornthwaite, C. (1996). Computer networks as social networks: Collaborative work, telework, and virtual community. Annual Review of Sociology, 22(1), 213-238. https://doi.org/10.1146/annurev.soc.22.1.213

Wilson, R.E., Gosling, S.D. \& Graham, L.T. (2012). A review of Facebook research in the social sciences. Perspectives on Psychological Science, 7(3), 203-220. https://doi.org/10.1177/1745691612442904

Wilson, S.M. \& Peterson, L.C. (2002). The Anthropology of online communities. Annual Review of Anthropology, 31(1), 449-467. https://doi.org/10.1146/annurev.anthro.31.040402.085436 
Nikishina, V.B., Sokolskaya, M.V., Musatova, O.A., Zapesotskaya, I.V., Danilova, A.V.\& Balykina, A.M. (2021). Type the title of your paper. World Journal on Educational Technology: Current Issues. 13(4), 863-889. https://doi.org/10.18844/wjet.v13i4.6272

Wynn, E. \& Katz, J. (1997). Hyperbole over Cyberspace: Self-Presentation and social boundaries in Internet home pages and discourse. The Information Society, 13(4), 297-327. https://doi.org/10.1080/019722497129043

Yushau, B., \& Nannim, F.A. (2020). Investigation into the Utilization of ICT Facilities for Teaching Purposes among University Lecturers: Influence of Gender, Age, Qualification and Years of Teaching Experience. Pedagogical Research, 5(2), em0054. https://doi.org/10.29333/pr/7845

Zakaria, N. (2017). Emergent patterns of Switching behaviors and intercultural communication styles of global virtual teams during distributed decision making. Journal of International Management, 23(4), 350-366. https://doi.org/10.1016/i.intman.2016.09.002

Zhao, S., Grasmuck, S. \& Martin, J. (2008). Identity construction on Facebook: Digital empowerment in anchored relationships. Computers in Human Behavior, 24(5), 1816-1836. https://doi.org/10.1016/J.CHB.2008.02.012 